$811.16 \cdot 367.622^{\prime} 366.52$

https://doi.org/10.18485/sj.2020.25.1.35

ПРЕДРАГ М. ОБУЋИНА*

Универзитет у Београду

Филолошки факултет
Оригинални научни рад

Примљен: 15. 10. 2019.

Прихваћен: 15. 01. 2020.

\title{
РОД ИМЕНИЦА У СЛОВЕНСКИМ ЈЕЗИЦИМА КАО СЕМАНТИЧКА, МОРФОЛОШКА И СИНТАКСИЧКА КАТЕГОРИЈА - НА ПРИМЕРУ ИМЕНИЦЕ НАОЧАРИ
}

У раду се износи теза да граматичка категорија рода именица функционише паралелно на морфолошком, синтаксичком и семантичком нивоу, те да односи између ових нивоа функционисања могу бити конвергентни, али и дивергентни, зависно од именице. Представљена је огледна методологија за дефинисање граматичке категорије рода, одређују се функције рода у односу на ванјезичку стварност и унутрашњу реченичну структуру (екстрарелација, интрарелација), а затим се род описује као морфолошки, синтаксички и семантички тип. Метод који се користи је формално-дистрибутивни. Током анализе дефинише се род именице наочари на три поменута нивоа - реконструише се њена морфолошка парадигма, анализирају се елементи њене семантичке структуре и утврђује се дистрибуција облика рода њеног конгруентног детерминатора. Затим се добијене информације укрштају и емпиријски се потврђују хипотезе које су већ изнете у вези са том проблематиком у ранијим радовима истакнутих српских граматичара. На крају се изводе одређени теоријски закључци у вези са методолошким ограничењима у постојећој граматичкој теорији и предлажу унапређења која би водила у смеру проширивања обима појма конгруенције.

Кључне речи: синтакса, морфологија, конгруенција, граматичка категорија рода, род именица, екстрарелацијска функција, интрарелацијска функција, граматичка дистрибуција

"predrago@fil.bg.ac.rs 


\section{1. ТЕОРИЈСКЕ ПРЕМИСЕ О ГРАМАТИЧКОЈ КАТЕГОРИЈИ РОДА КОД ИМЕНИЦА}

Када се говори о граматичкој категорији рода, најшире прихваћен приступ у српској граматичкој мисли јесте да се он дефинише у оквиру опозиције граматички : природни (Стевановић 1975; Симић 1996; Станојчић/Поповић 1997; Кликовац 2002). Ограничења таквог становишта су већ раније била изнета и изложена критици у стручним радовима, било у блажој или нешто оштријој форми (Томић 2011; Николић 2004), тако да их у овом огледу нећемо понављати, већ ћемо покушати да оцртамо оквире једне експлицитне и неинтуитивне методологије, чијом применом би се решили неки од примећених проблема. Успешност такве методологије могао би се просуђивати на основу њене способности да без остатка (или са што мањим остатком) даје одговор на питање којег рода је произвољна именица српског, али последично и неког другог словенског, па чак и било ког другог језика који поседује граматичку категорију рода. Методологију ћемо представити кроз анализу рода именице наочари.

За потребе овог огледа дајемо радну дефиницију граматичке категорије: граматичка категорија је информација о делу стварности која нас окружује и коју перцепирамо најчешће у облику простих или сложених опозиција (по могућности представљених бинарно), а које су изражене граматичким средствима, нпр. наставцима. Дакле, у односу који дефиниција описује, с једне стране налазе се појавни облици стварности које људски ум спознаје и, у складу са својом природом, тежи да их класификује, да им да̂ смисао, док су са друге стране језичке јединице сублексичког нивоа (наставци) које служе за њихово обележавање, тј. којима их именује. У складу са дефиницијом, истраживање појединачних граматичких категорија, у овом случају конкретно рода, мора поћи од а) типологије појавних облика рода у природи и б) од типологије наставака за означавање тог рода, на чему је и заснована подела на природни (семантички) и граматички (морфолошки) род.

На плану лексичке семантике и морфологије, подела рода на природни и граматички оправдана је и не ствара проблеме у анализи, пре свега због тога што те лингвистичке дисциплине за свој предмет имају семантичку или формалну структуру појединачних речи. На плану синтаксе у жижи су односи између две или више лексичких јединица, на пример у именичко-придевској синтагми, где долази до интеракције облика граматичког и природног рода именице, с једне стране, са парадигматским родом придева који се усклађује према именици по посебним правилима. Према томе, категорија рода, осим описане функције да наставцима обележава припадност именице једном семантичком или морфолошком типу, има још и функцију да успостави структурну синтаксичку везу између именица и придева. 
Овакво секундарно (синтаксичко) дефинисање рода именице, тј. на основу морфолошког усклађивања облика придева у синтагми са њом, није новина у српској граматици - још је Александар Белић (1934: 57) приметио да се род ,[...]познаје или према природном роду (природни род) именице или по придеву или заменици атрибутски употребљеним уз именице, јер придеви и придевске заменице имају нарочите наставке за сваки род [...]". Милка Ивић анализирала је у више наврата род именица на семантичком, морфолошком и синтаксичком плану, као и њихове међуодносе, полазећи са формално-дистрибутивног становишта: „[...]обележавање рода именица постиже се на два начина: А) деклинационом структуром саме именице, тј. парадигматским (П) моментом; Б) деклинационим обликом присутног детерминатива, тј. конгруенцијским (К) моментом" (Ивић 1960: 192). У серији њених каснијих радова, који су изузетно богати закључцима, преовладава став да је синтаксички моменат главни критеријум за одређивање рода именице: „Imenički rod je gramatička pojava koja se manifestuje pre svega u činjenici da svaka srpskohrvatska imenica u svom osnovnom obliku (nom.sg.) dobija jedan od sledeća tri u principu moguća kongruencijska (K) tipa atributa: ili 'muški' (taj) ili 'ženski' (ta) ili 'srednji' (to). Prema tome koji je kongruencijski tip u kojem slučaju zastupljen, imenica je određena kao muškog, ženskog ili srednjeg roda [...] Rod se ne pokazuje samo kongruencijom već i paradigmom (P) imenice, mada je uloga kongruencije ovde očigledno primarna, a paradigme sekundarna, konkomitantna" (Ivić 1966: 41).

Са таквом теоријском премисом, у чијој је примени остала прилично усамљена, Ивић је анализирала род именица у српском (Ивић 1966), пољском (Ivić 1967) и словеначком језику (Ивић 1968), описујући компликоване трансформације у парадигми именица (П) и њихове односе са индикатором конгруенције (К). Циљ тих истраживања био је испитивање предиктабилности конгруенцијског момента К у односу на парадигматски П, те дефинисање типологије односа између та два момента. Без сумње, ради се о пионирском подухвату који уноси другачији поглед на феномен рода у српску граматику, али и у славистичка граматичка истраживања уопште, што се види по чињеници да од шездесетих година 20. века расте интересовање за улогу конгруенције у дефинисању рода у словенском свету и јављају се нови појмови, као што је нпр. конгруениијска класа или на руском согласовательный класс (Зализњак 1964: 26).

Према томе, када говоримо о граматичкој категорији рода именица у српском, дакле и у осталим словенским језицима, можемо узети у обзир три нивоа анализе: морфолошки, семантички и синтаксички, а хијерархија између њих може зависити од личних теоријских афинитета и варирати од истраживача до истраживача. Ми сматрамо да у науци о језику примарност треба дефинисати по степену сложености језичких јединица и њиховој доступ- 
ности емпиријској анализи: род је за нас граматичка категорија која се најпре реализује као морфолошки тип (1), тј. као тип парадигме, која има своје како интрарелацијске, тако и екстрарелацијске функције. Под интрарелацијским функцијама разумемо улогу граматичке категорије рода у формирању синтаксичких конструкција (2), дакле на плану унутарњих односа у реченици, док као екстрарелацијске функције разумемо способност граматичке категорије рода да означи елементе структуре смисла и однесе се према ванјезичкој стварности коју означава (3).

\section{2. РОД ИМЕНИЦЕ 'НАОЧАРИ'}

Род именице као њен семантички, морфолошки и синтаксички тип може, али и не мора имати исте вредности. Именица као што је нпр. мушкараи, обележава денотате природног мушког рода (мушки семантички тип), има „мушку” парадигму, тј. карактеристичан образац промене (мушки морфолошки тип) и гради синтаксичке групе са придевима у мушком роду, као што су леп, велик, добар (мушки синтаксички тип). Аналогно томе именица жена спада у женски семантички тип јер обележава денотате природног женског рода, у женски морфолошки тип јер има „женску” промену и у женски синтаксички тип јер гради синтаксичке групе са придевима у женском роду лепа, велика, добра. Код тих примера долази до подударања рода као семантичког, морфолошког и синтаксичког типа. Међутим, нешто сложенију слику проналазимо код именице наочари.

\section{1. Морфолошки тип именице 'наочари'}

Морфолошки (парадигматски) тип лексеме наочари није једноставно дефинисати. Два најважнија описна речника српског језика (РСКЈ, РСКНЈ) у номинативу бележе дублетне облике наочари, наочаре и наочале, који се не мењају по броју (pluralia tantum). Трећи наведени облик има ограничен опсег употребе у географском смислу и користи се претежно на западу језичке територије. За ту варијанту нема недоумице: ради се о именици женског граматичког рода, са обрасцем промене типа санке. Дефинисање морфолошког типа друга два дублета представља изазовнији задатак. РСКЈ одређује лексему као именицу женског рода множине, док РСКНЈ описује лексему као именицу женског и мушког рода. Нажалост, ниједан од речника не даје пун инвентар облика лексеме, тако да није јасно која од варијаната је женског, а која мушког рода: наиме, и именице женског рода на консонант имају наставак -и у номинативу множине, истоветно као и именице мушког рода на консонант. Стога располажемо трима могућностима: а) именица може имати промену као друге 
именице женског рода на - $a$, или б) као именице женског рода на консонант, или в) као именице мушког рода на консонант (наравно, у сва три случаја искључиво у множини, пошто се ради о именици без парадигме по броју).

Анализа примера употребе облика лексеме из речника не даје закључке о њеном морфолошком типу на основу којих би се могла искључити барем једна од наведене три теоријске могућности. РСКЈ даје само један пример:

(1) Погледа ме преко наочари.

који упућује на то да се ова лексема мења по падежима као именице женског рода на консонант, иако у заглављу речничког чланка стоји да је наставак за генитив само -ара, чиме се лексема сврстава у именице женског рода на - $a$. Овај речник не допушта могућност да је у питању именица мушког рода.

С друге стране, РСКНЈ даје више грађе, али и више могућности за одређивање морфолошког типа. Следећи примери категоризују наведену лексему у именице женског рода на $-a^{1}$ :

(2) Наочаре на носу су се одједном замаглиле...

(3) Натенане извади наочаре...

(4) Постоје сличне идеолошке наочаре и за радничке очи...

(5) Просуђивати кроз наочаре нашега старога Рунка...

(6) Види неколико госпа и госпојица са којима се тек на наочаре може разговарати.

Следећи примери сврставају лексему у категорију женски род на консонант:

(7) Уздигавши на чело авијатичарске наочари...

(8) Погледа ме преко наочари...

(9) Но нека он за Германце и за оне који њиним наочарима гледају, пише како му се свиди.

(10) Често је социолошки поглед замагљен наочарима пруског романтичара...

(11) Срби метнули султану наочари...

Следећи примери категоришу лексему у мушки род на консонант:

(3) Натенане извади наочаре...

(5) Просуђивати кроз наочаре нашега старога Рунка

(6) Види неколико госпа и госпојица са којима се тек на наочаре може разговарати.

(9) Но нека он за Германце и за оне који њиним наочарима гледају, пише како му се свиди.

${ }^{1}$ Услед синкретизма падежних облика, неким примерима се може истовремено илустровати више различитих морфолошких типова, али и дистрибутивних (конгруенцијских) класа. 
(10) Често је социолошки поглед замагљен наочарима пруског романтичара

(12) Тебе су очи здраве, а наочари добри.

Реконструкцију могућих образаца промене облика лексеме наочари/е табеларно можемо приказати на следећи начин:

\section{Табела 1. Упоредна парадигма реконструисаних облика} именице нао чари/е

\begin{tabular}{|c|c|c|c|}
\hline наочари/e & м. p. - & ж. p. $-\varnothing$ & ж. p. на $-\boldsymbol{a}$ \\
\hline Ном. & наочари & наочари & наочаре \\
\hline Ген. & наочара & наочари* & наочара \\
\hline Дат. & наочарима & наочарима & наочарама* \\
\hline Ак. & наочаре & наочари & наочаре \\
\hline Инс. & наочарима & наочарима & наочарама* \\
\hline Лок. & наочарима & наочарима & наочарама* \\
\hline Вок. & наочари & наочари & наочаре \\
\hline
\end{tabular}

Већ смо напоменули да речници не дају информације о томе који облици су неправилни, тј. који морфолошки тип се може елиминисати, тако да се све три промене могу сматрати правилним. Истини за вољу, језичком осећању данашњег образованог говорника најмање смета мушки морфолошки тип, код којега нема сумњивих облика, док у женским морфолошким типовима облици датива, инструментала и локатива наочарама (рецимо у конструкцији са наочарама) највероватније не би били прихватљиви, а слично би било и за облик генитива наочари (на пример у конструкцији без наочари), што означавамо звездицама у табели. На основу изложеног могло би се закључити да је именица наочари најшире прихваћена као мушки морфолошки тип.

Додатну аргументацију о припадности именице наочари мушком морфолошком типу можемо извести на основу морфолошке анализе творбе речи: у речи наочари/е могу се изоловати следеће морфеме:

на-оч(ок)-ар-и/е

где је на-префикс, оч(ок) - корен, тј. главни носилац семантике, -ар - творбени формант, -u/e - наставак за номинатив множине (око којег се тренутно двоумимо). Будући да се у српском језику формантом -ар граде именице мушког рода, са мушком променом, склони смо да мушки морфолошки тип посматрамо као исправнији у односу на друга два женска, барем у етимолошком смислу. 
Једнински облик са мушком променом наочар потврђен је посредно и непосредно: посредно у лексеми наочарка (нпр. кобра наочарка), која је добијена од њега моцијом (нпр. лекар - лекарка, станар - станарка...), а непосредно у синтагми медвед наочар, што је врста медведа која живи у Јужној Америци (лат. Tremarctos ornatus), карактеристична по карактеристичној шари на очима. Сви ови аргументи узети заједно снажно потврђују да лексема којом се означава наведено оптичко помагало у номинативу има облик наочари и да припада мушком морфолошком типу.

\section{2. Семантички тип именице 'наочари'}

Именица наочари означава предмет, што би значило да је њен семантички тип такав да она нема природни род. Ова информација открива чињеницу да је категорија аниматности у тесној вези са природним родом, наиме, аниматност је предуслов за постојање природног рода, па као таква треба да буде узета у обзир приликом анализе семантичке структуре категорије рода. Шематски се то може представити на следећи начин:

\section{Табела 2. Однос категорије аниматности и рода у семантичкој структури именица}

\begin{tabular}{|c|c|c|c|}
\hline \multicolumn{4}{|c|}{1 аниматност (поседовање природног рода) } \\
\hline \multicolumn{3}{|c|}{ 1.1. аниматно (има природни род) } & $\begin{array}{c}\text { 1.2. неаниматно } \\
\text { нема природни род }\end{array}$ \\
\hline 1.1.1. изражен род & 1.1.2. неизражен род средњи & - \\
\hline $\begin{array}{c}1.1 .1 .1 . \\
\text { мушки }\end{array}$ & $\begin{array}{c}1.1 .1 .2 . \\
\text { женски }\end{array}$ & - & - \\
\hline
\end{tabular}

Из тога следи да граматичка категорија рода за именицу наочари нема екстрарелацијску функцију, што се тиче природног рода (не упућује на природни род у стварности), те да су њене функције искључиво интрарелацијске (на плану унутрашње структуре реченице). Последично се тај закључак може пренети на све именице категорије неживо.

\section{3. Синтаксички тип именице 'наочари'}

Род као синтаксички тип именице наочари условљен је интрарелацијским функцијама граматичке категорије рода, тј. комбинаторичким могућностима за спајање облика именице наочале, наочари/е са облицима придева у одговарајућем роду, на основу чега дефинишемо дистрибутивну (конгруенцијску) 
класу лексеме, другим речима, одређујемо њен род као синтаксичку особину. Наш конкретан циљ јесте да испитамо, тј. дијагностикујемо са којим облицима придева у позицији конгруентног атрибута анализирана реч може формирати правилне конструкције, о чему прикупљамо емпиријске податке и изолујемо релевантне информације дедуктивном методом. У ту сврху дефинишемо дијагностички контекст који се састоји од свих облика придева (нпр. добар), измењаних по падежу, роду и броју, сложених табеларно ${ }^{2}$. Анализу вршимо тако што у табелу поред облика придева уписујемо облике именице чији синтаксички тип дијагностикујемо, водећи рачуна о облику падежа, а затим добијене комбинације оцењујемо као правилне или неправилне на основу тога да ли се дата комбинација облика може интерпретирати као конструкција српског језика, тј. да ли бисмо такву комбинацију могли употребити или чути приликом комуникације са другим говорницима српског као матерњег језика. Дајемо пример за варијанту лексеме наочале:

\section{Табела 3. Дијагностиковање синтаксичког типа}

\section{лексеме наочале}

\begin{tabular}{|c|c|c|c|c|c|c|c|}
\hline & M. p. j. (ж.) & $\begin{array}{l}\text { м. p. j. } \\
\text { (нж.) }\end{array}$ & ж. p. j. & c. p. j. & м. р. мн. & ж. p. мн. & c. p. мн. \\
\hline $\mathrm{H}$ & $\begin{array}{l}\text { *добар } \\
\text { наочале }\end{array}$ & $\begin{array}{l}\text { *добар } \\
\text { наочале }\end{array}$ & $\begin{array}{l}\text { *добра } \\
\text { наочале }\end{array}$ & $\begin{array}{l}\text { *добро } \\
\text { наочале }\end{array}$ & $\begin{array}{l}\text { *добри } \\
\text { наочале }\end{array}$ & $\begin{array}{c}\text { добре } \\
\text { наочале }\end{array}$ & $\begin{array}{l}\text { *добра } \\
\text { наочале }\end{array}$ \\
\hline$\Gamma$ & $\begin{array}{l}\text { *доброг } \\
\text { наочала }\end{array}$ & $\begin{array}{c}\text { *доброг на- } \\
\text { очала }\end{array}$ & $\begin{array}{c}\text { *добре } \\
\text { наочала }\end{array}$ & *доброг наочала & $\begin{array}{c}\text { (?) добрих } \\
\text { наочала }\end{array}$ & $\begin{array}{c}\text { добрих } \\
\text { наочала }\end{array}$ & $\begin{array}{c}\text { (?) добрих } \\
\text { наочала }\end{array}$ \\
\hline Д & $\begin{array}{c}\text { *добром } \\
\text { наочалама }\end{array}$ & $\begin{array}{c}\text { *добром } \\
\text { наочалама }\end{array}$ & $\begin{array}{c}\text { *доброј } \\
\text { наочалама }\end{array}$ & $\begin{array}{c}\text { *добром } \\
\text { наочалама }\end{array}$ & $\begin{array}{l}\text { (?) добрим } \\
\text { наочалама }\end{array}$ & $\begin{array}{c}\text { добрим } \\
\text { наочалама }\end{array}$ & $\begin{array}{l}\text { (?) добрим } \\
\text { наочалама }\end{array}$ \\
\hline A & $\begin{array}{l}\text { *доброг } \\
\text { наочале }\end{array}$ & $\begin{array}{c}\text { *добар } \\
\text { наочале }\end{array}$ & $\begin{array}{l}\text { *добру } \\
\text { наочале }\end{array}$ & *добро наочале & $\begin{array}{l}\text { (?) добре } \\
\text { наочале }\end{array}$ & $\begin{array}{c}\text { добре } \\
\text { наочале }\end{array}$ & $\begin{array}{c}\text { *добра } \\
\text { наочале }\end{array}$ \\
\hline И & $\begin{array}{l}\text { (?) добрим } \\
\text { наочалама }\end{array}$ & $\begin{array}{l}\text { (?) добрим } \\
\text { наочалама }\end{array}$ & $\begin{array}{c}\text { *добром } \\
\text { наочалама }\end{array}$ & $\begin{array}{l}\text { (?) добрим } \\
\text { наочалама }\end{array}$ & $\begin{array}{l}\text { (?) добрим } \\
\text { наочалама }\end{array}$ & $\begin{array}{c}\text { добрим } \\
\text { наочалама }\end{array}$ & $\begin{array}{l}\text { (?) добрим } \\
\text { наочалама }\end{array}$ \\
\hline Л & $\begin{array}{c}\text { *добром } \\
\text { наочалама }\end{array}$ & $\begin{array}{c}\text { *добром } \\
\text { наочалама }\end{array}$ & $\begin{array}{c}\text { *доброј } \\
\text { наочалама }\end{array}$ & $\begin{array}{c}\text { *добром наоча- } \\
\text { лама }\end{array}$ & $\begin{array}{l}\text { (?) добрим } \\
\text { наочалама }\end{array}$ & $\begin{array}{c}\text { добрим } \\
\text { наочалама }\end{array}$ & $\begin{array}{l}\text { (?) добрим } \\
\text { наочалама }\end{array}$ \\
\hline B & $\begin{array}{l}\text { *добри } \\
\text { наочале }\end{array}$ & $\begin{array}{l}\text { *добри } \\
\text { наочале }\end{array}$ & $\begin{array}{l}\text { *добра } \\
\text { наочале }\end{array}$ & $\begin{array}{l}\text { *добро } \\
\text { наочале }\end{array}$ & $\begin{array}{l}\text { *добри } \\
\text { наочале }\end{array}$ & $\begin{array}{c}\text { добре } \\
\text { наочале }\end{array}$ & $\begin{array}{l}\text { *добра } \\
\text { наочале }\end{array}$ \\
\hline
\end{tabular}

Дијагностички контекст даје три типа резултата: а) правилне (означене подебљаним словима), б) неправилне (означене курзивом и звездицом) и в) привидно правилне комбинације облика именица и придева (означене знаком питања). Неправилним сматрамо оне комбинације које не бисмо сами користили и који нису потврђени у комуникацији на српском језику код других говорника. Привидно су правилни они резултати код којих облици придева и именица наизглед дају добре комбинације у појединачним падежима, али не и кроз целу парадигму. Правилни су они резултати који кроз читаву парадигму

${ }^{2}$ Из практичних разлога изостављамо категорију придевског вида јер она није информативна за наш оглед. 
дају добре комбинације облика именица и придева, употребљиве у комуникацији на српском језику. У случају речи наочале, правилне комбинације се добијају помоћу облика придева добар у женском роду, а пошто реч наочале спада у морфолошки женски тип (мења се по женској промени), то значи да се њен морфолошки и синтаксички тип поклапају. Стога закључујемо да варијанта лексеме наочале припада истој дистрибутивној (конгруенцијској) класи као и лексема санке, тј. придеви конгруирају са тим лексемама на исти начин - у женском роду множине у свим падежима.

Испитивање комбинаторичких способности других реконструисаних морфолошких типова лексеме наочари/е за повезивање са облицима придева у дијагностичком контексту даје интересантне резултате. Нпр. варијанта лексеме наочаре (,женски” морфолошки тип на -a) даје следеће синтаксичке групе са облицима придева:

Табела 4. Дијагностиковање синтаксичког типа именице н а о ч а р е (ж.р.- $a$ )

\begin{tabular}{|c|c|c|c|c|c|c|c|}
\hline & M. p. j. (ж.) & м. p. j. (нж.) & ж. p. j. & c. p. j. & м. p. мн. & ж. р. мн. & c. p. мн. \\
\hline $\mathrm{H}$ & $\begin{array}{c}\text { *добар } \\
\text { наочаре }\end{array}$ & $\begin{array}{c}\text { *добар } \\
\text { наочаре }\end{array}$ & $\begin{array}{c}\text { *добра } \\
\text { наочаре }\end{array}$ & $\begin{array}{c}\text { *добро } \\
\text { наочаре }\end{array}$ & $\begin{array}{c}\text { *добри } \\
\text { наочаре }\end{array}$ & $\begin{array}{l}\text { (?) добре } \\
\text { наочаре }\end{array}$ & $\begin{array}{c}\text { *добра } \\
\text { наочаре }\end{array}$ \\
\hline$\Gamma$ & $\begin{array}{l}\text { *доброг } \\
\text { наочара }\end{array}$ & $\begin{array}{l}\text { *доброг } \\
\text { наочара }\end{array}$ & $\begin{array}{c}\text { *добре } \\
\text { наочара }\end{array}$ & $\begin{array}{r}\text { *доброг } \\
\text { наочара }\end{array}$ & $\begin{array}{l}\text { (?) добрих } \\
\text { наочара }\end{array}$ & $\begin{array}{c}\text { (?) добрих } \\
\text { наочара }\end{array}$ & $\begin{array}{c}\text { (?) добрих } \\
\text { наочара }\end{array}$ \\
\hline Д & $\begin{array}{c}\text { *добром } \\
\text { наочарама }\end{array}$ & $\begin{array}{c}\text { *добром } \\
\text { наочарама }\end{array}$ & $\begin{array}{c}\text { *доброј } \\
\text { наочарама }\end{array}$ & $\begin{array}{c}\text { *добром } \\
\text { наочарама }\end{array}$ & $\begin{array}{l}\text { (?) добрим } \\
\text { наочарама }\end{array}$ & $\begin{array}{l}(*) \text { добрим } \\
\text { наочарама }\end{array}$ & $\begin{array}{l}\text { (?) добрим } \\
\text { наочарама }\end{array}$ \\
\hline A & $\begin{array}{c}\text { *доброг } \\
\text { наочаре }\end{array}$ & $\begin{array}{c}\text { *добар } \\
\text { наочаре }\end{array}$ & $\begin{array}{c}\text { *добру } \\
\text { наочаре }\end{array}$ & $\begin{array}{c}\text { *добро } \\
\text { наочаре }\end{array}$ & $\begin{array}{l}\text { (?) добре } \\
\text { наочаре }\end{array}$ & $\begin{array}{c}\text { (?) добре } \\
\text { наочаре }\end{array}$ & $\begin{array}{c}\text { *добра } \\
\text { наочаре }\end{array}$ \\
\hline И & $\begin{array}{l}\text { (?) добрим } \\
\text { наочарама }\end{array}$ & $\begin{array}{l}\text { (?) добрим } \\
\text { наочарама }\end{array}$ & $\begin{array}{c}\text { *добром } \\
\text { наочарама }\end{array}$ & $\begin{array}{l}\text { (?) добрим } \\
\text { наочарама }\end{array}$ & $\begin{array}{l}\text { (?) добрим } \\
\text { наочарама }\end{array}$ & $\begin{array}{l}(*) \text { добрим } \\
\text { наочарама }\end{array}$ & $\begin{array}{l}\text { (?) добрим } \\
\text { наочарама }\end{array}$ \\
\hline Л & $\begin{array}{c}\text { *добром } \\
\text { наочарама }\end{array}$ & $\begin{array}{c}\text { *добром } \\
\text { наочарама }\end{array}$ & $\begin{array}{c}\text { *доброј } \\
\text { наочарама }\end{array}$ & $\begin{array}{c}\text { *добром } \\
\text { наочарама }\end{array}$ & $\begin{array}{l}\text { (?) добрим } \\
\text { наочарама }\end{array}$ & $\begin{array}{l}(*) \text { добрим } \\
\text { наочарама }\end{array}$ & $\begin{array}{l}\text { (?) добрим } \\
\text { наочарама }\end{array}$ \\
\hline B & $\begin{array}{c}\text { *добри } \\
\text { наочаре }\end{array}$ & $\begin{array}{c}\text { *добри } \\
\text { наочаре }\end{array}$ & $\begin{array}{c}\text { *добра } \\
\text { наочаре }\end{array}$ & $\begin{array}{c}\text { *добро } \\
\text { наочаре }\end{array}$ & $\begin{array}{c}\text { *добри } \\
\text { наочаре }\end{array}$ & $\begin{array}{l}\text { (?) добре } \\
\text { наочаре }\end{array}$ & $\begin{array}{c}\text { *добра } \\
\text { наочаре }\end{array}$ \\
\hline
\end{tabular}

Иако их неки говорници можда и не доживљавају као неправилне, не може се занемарити чињеница да синтагме *добрим наочарама у дативу, инструменталу и локативу могу звучати необично уху осетљивог говорника, или у најмању руку дијалекатски. Због тога у овом дијагностичком контексту није могуће изоловати ниједну парадигму, тј. ниједан синтаксички тип који је исправан у целости. Слична ситуација је и са лексемом женске промене на консонант наочари, код које проблем прави генитивска синтагма *лепих наочари: 


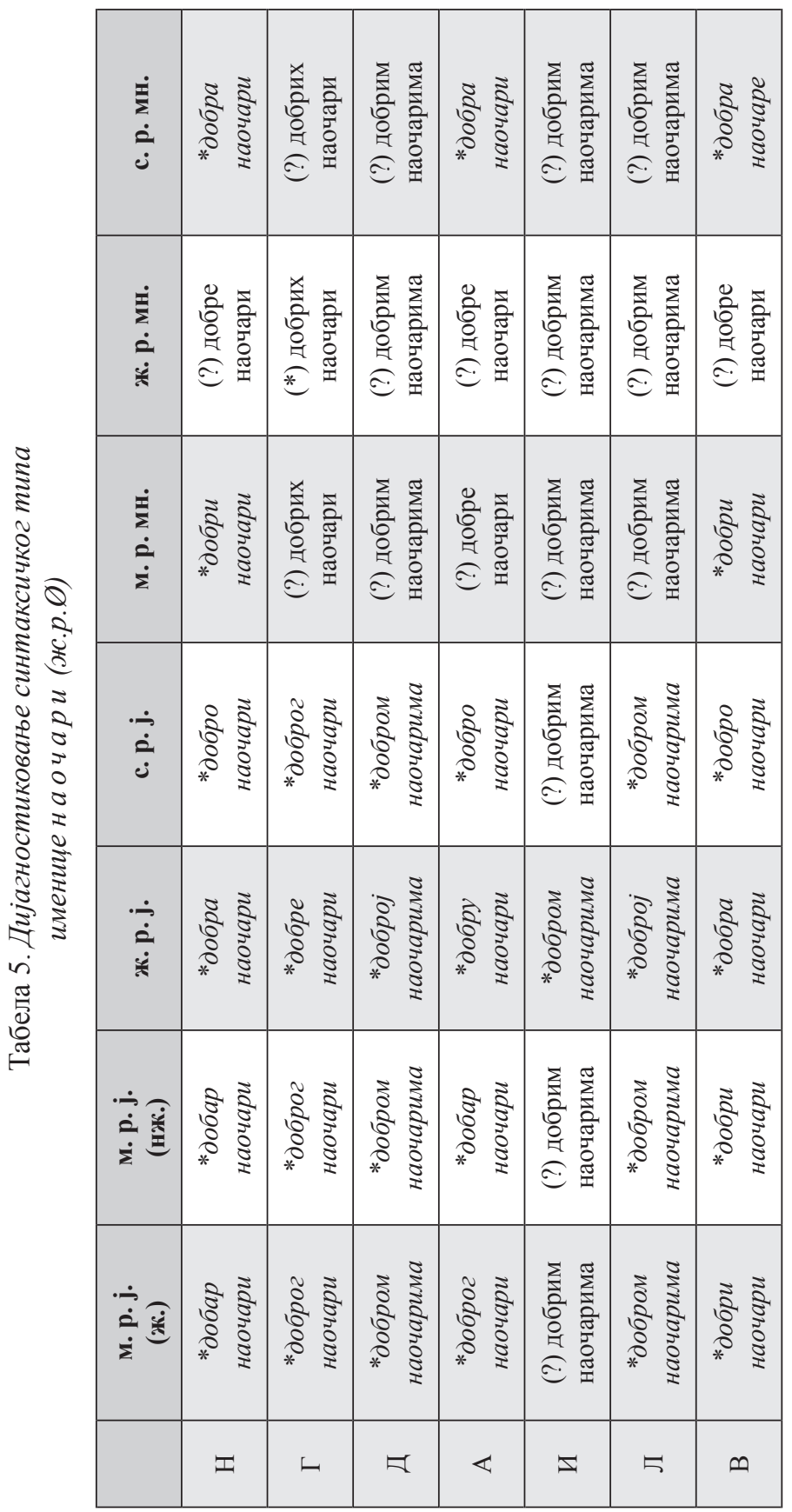


Анализа мушког морфолошког типа даје неочекиване резултате. Према устаљеној дефиницији конгруенције као усклађивања зависних синтаксичких јединица са граматичким облицима и/или значењима јединица које имају самосталнији синтаксички статус (Пипер и др. 2005: 75), очекивано би било да се облици придева у мушком роду повезују са облицима именице мушког морфолошког типа. Међутим, емпиријска анализа показује другачије:

Табела 6. Дијагностиковање синтаксичког типа именице нао ч ар и (м.р.Ø)

\begin{tabular}{|c|c|c|c|c|c|c|c|}
\hline & $\begin{array}{l}\text { M. p. j. } \\
\text { (ж.) }\end{array}$ & $\begin{array}{l}\text { M. p. j. } \\
\text { (нж.) }\end{array}$ & ж. p. j. & c. p. j. & м. р. мн. & ж. р. мн. & с. p. мн. \\
\hline $\mathrm{H}$ & $\begin{array}{c}\text { *добар } \\
\text { наочари }\end{array}$ & $\begin{array}{c}\text { *добар } \\
\text { наочари }\end{array}$ & $\begin{array}{c}\text { *добра } \\
\text { наочари }\end{array}$ & $\begin{array}{c}\text { *добро } \\
\text { наочари }\end{array}$ & $\begin{array}{c}\text { *добри } \\
\text { наочари }\end{array}$ & $\begin{array}{c}\text { добре } \\
\text { наочари }\end{array}$ & $\begin{array}{c}\text { *добра } \\
\text { наочари }\end{array}$ \\
\hline$\Gamma$ & $\begin{array}{c}\text { *доброг } \\
\text { наочара }\end{array}$ & $\begin{array}{c}\text { *доброг } \\
\text { наочара }\end{array}$ & $\begin{array}{c}\text { *добре } \\
\text { наочара }\end{array}$ & $\begin{array}{l}\text { *доброг } \\
\text { наочара }\end{array}$ & $\begin{array}{c}\text { (?) добрих } \\
\text { наочара }\end{array}$ & $\begin{array}{c}\text { добрих } \\
\text { наочара }\end{array}$ & $\begin{array}{c}\text { (?) добрих } \\
\text { наочара }\end{array}$ \\
\hline Д & $\begin{array}{c}\text { *добром } \\
\text { наочарима }\end{array}$ & $\begin{array}{c}\text { *добром } \\
\text { наочарима }\end{array}$ & $\begin{array}{c}\text { *доброј } \\
\text { наочарима }\end{array}$ & $\begin{array}{c}\text { *добром } \\
\text { наочарима }\end{array}$ & $\begin{array}{l}\text { (?) добрим } \\
\text { наочарима }\end{array}$ & $\begin{array}{c}\text { добрим } \\
\text { наочарима }\end{array}$ & $\begin{array}{l}\text { (?) добрим } \\
\text { наочарима }\end{array}$ \\
\hline A & $\begin{array}{l}\text { *доброг } \\
\text { наочаре }\end{array}$ & $\begin{array}{c}\text { *добар } \\
\text { наочаре }\end{array}$ & $\begin{array}{c}\text { *добру } \\
\text { наочаре }\end{array}$ & $\begin{array}{c}\text { *добро } \\
\text { наочаре }\end{array}$ & $\begin{array}{l}\text { (?) добре } \\
\text { наочаре }\end{array}$ & $\begin{array}{c}\text { добре } \\
\text { наочаре }\end{array}$ & $\begin{array}{c}\text { *добра } \\
\text { наочаре }\end{array}$ \\
\hline И & $\begin{array}{l}\text { (?) добрим } \\
\text { наочарима }\end{array}$ & $\begin{array}{l}\text { (?) добрим } \\
\text { наочарима }\end{array}$ & $\begin{array}{c}\text { *добром } \\
\text { наочарима }\end{array}$ & $\begin{array}{l}\text { (?) добрим } \\
\text { наочарима }\end{array}$ & $\begin{array}{l}\text { (?) добрим } \\
\text { наочарима }\end{array}$ & $\begin{array}{c}\text { добрим } \\
\text { наочарима }\end{array}$ & $\begin{array}{l}\text { (?) добрим } \\
\text { наочарима }\end{array}$ \\
\hline Л & $\begin{array}{c}\text { *добром } \\
\text { наочарима }\end{array}$ & $\begin{array}{c}\text { *добром } \\
\text { наочарима }\end{array}$ & $\begin{array}{c}\text { *доброј } \\
\text { наочарима }\end{array}$ & $\begin{array}{c}\text { *добром } \\
\text { наочарима }\end{array}$ & $\begin{array}{l}\text { (?) добрим } \\
\text { наочарима }\end{array}$ & $\begin{array}{c}\text { добрим } \\
\text { наочарима }\end{array}$ & $\begin{array}{l}\text { (?) добрим } \\
\text { наочарима }\end{array}$ \\
\hline B & $\begin{array}{c}\text { *добри } \\
\text { наочари }\end{array}$ & $\begin{array}{c}\text { *добри } \\
\text { наочари }\end{array}$ & $\begin{array}{c}\text { *добра } \\
\text { наочари }\end{array}$ & $\begin{array}{c}\text { *добро } \\
\text { наочари }\end{array}$ & $\begin{array}{c}\text { *добри } \\
\text { наочари }\end{array}$ & $\begin{array}{c}\text { добре } \\
\text { наочари }\end{array}$ & $\begin{array}{c}\text { *добра } \\
\text { наочаре }\end{array}$ \\
\hline
\end{tabular}

Парадигма придева у мушком и женском роду множине уједначена је у свим падежима, осим у номинативу и вокативу, због чега управо ова два облика одлучују о роду као синтаксичкој особини дијагностиковане лексеме. Номинативски и вокативски облик *лепи наочари врло ретко се срећу у комуникацији и образовани говорници готово их уопште не користе, због чега мушки род мора бити одбачен као неприхватљив. Са друге стране, ниједна од синтагми са придевима у женском роду множине не звучи ни неуобичајено, ни дијалекатски, ни архаично кроз читаву парадигму. Због тога се, и поред тога што се мења по мушкој промени, мора закључити да се лексема наочари најбоље повезује са облицима придева у женском роду, те да стога припада женском синтаксичком типу.

Међуоднос анализираних облика табеларно се може приказати на следећи начин (МТ - морфолошки тип, СТ - синтаксички тип): 


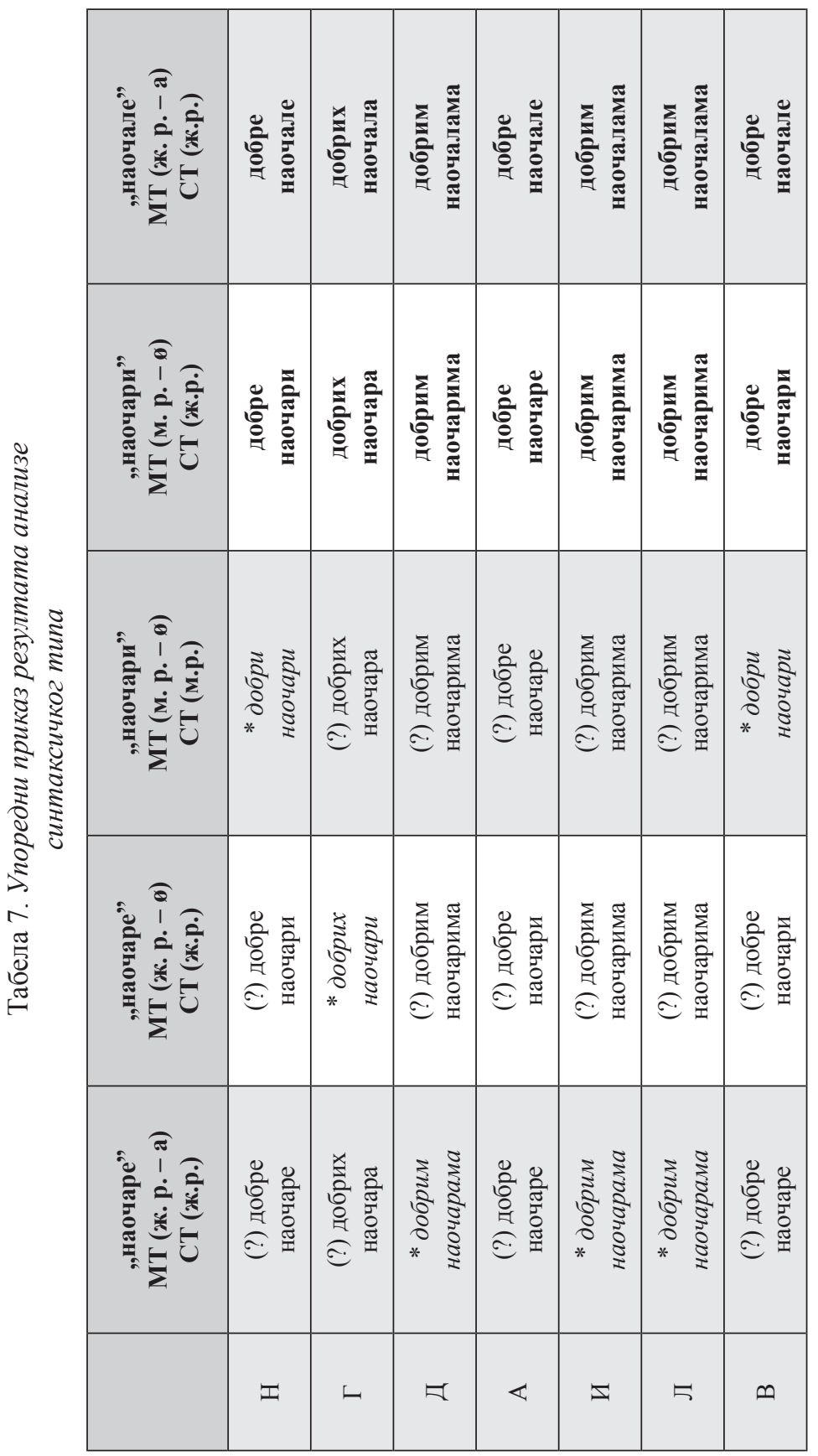




\section{4. ЗАКЉУЧАК}

Горе изнета емпиријска анализа недвосмислено потврђује хипотезу Михаила Стевановића у вези са родом именице наочари: „И ма колико да је необјашњиво којим путем је до такве употребе дошло, ја мислим да противу ње не треба устајати. Зато и држим да у практичним граматикама и речницима именицу наочари треба означавати као именицу мушког рода, с напоменом да се у номинативу акузативу, а можда и другим падежима употребљава и с облицима женског рода [...]”. (Стевановић 1937: 208)

У нашем огледу показали смо да у случају именице наочари граматичка категорија рода функционише дивергентно на различитим нивоима анализе: облички, та именица припада мушком морфолошком типу (мења се по мушкој промени); значењски, она припада неаниматном семантичком типу, због чега граматичка категорија рода за ту именицу нема екстрарелацијску функцију (не упућује на природни род); на плану интрарелације, тј. односа са другим речима у реченици, наочаре припадају женском синтаксичком типу (повезује се са облицима женског рода у синтаксичким односима са речима са парадигматском категоријом рода). У свакодневној језичкој комуникацији несумњиво има доста колебања у вези са овом лексемом, а нормативна граматика савременог српског језика за сада нема недвосмислене препоруке што се тиче морфолошке парадигме лексеме наочари и правила њеног комбиновања са облицима придева. Надамо се да ће у решавању овог проблема у будућности допринети и наша анализа.

Наш рад доноси и одређене закључке на теоријском плану: дивергенција семантичког и морфолошког типа именица сматра се уобичајеном и не изазива чуђење, вероватно захваљујући давно прихваћеној опозицији граматички : природни, што је теоријско гледиште које омогућава описивање различитих вредности природног рода које корелирају са различитим обрасцима морфолошке промене (нпр. реч чика има граматички женски, а природни мушки род). За разлику од тога, о односу морфолошког и синтаксичког типа именица, који је вероватно подједнако хетероген, у нашој граматици доста се ретко говори, вероватно због тога што актуелна синтаксичка теорија не подржава анализу у том правцу. Преиспитивање теоријских становишта којима се намећу некорисна ограничења, уз претходну емпиријску анализу, са експлицитно дефинисаном методологијом, која се доследно примењује непосредно на језички материјал, у циљу прецизирања кључних појмова граматике (нпр. конгруенције), довело би до битног помака како на плану граматичке теорије тако и на плану језичке културе. 


\section{Извори}

РСКЈ - Речник српскохрватскога књижевног језика. Нови Сад : Матица српска; Загреб: Матица хрватска, 1967.

РСКНЈ - Речник српскохрватског књижевног и народног језика. Београд: САНУ; Институт за српскохрватски језик, 1959-.

\section{ЛИТЕРАТУРА}

Белић 1934: Александар Белић, Граматика српскохрватског језика за други разред средюих и стручних школа, друго издање, Београд: Геца Кон.

Зализњак 1964: Андрей Анатольевич Зализняк, К вопросу о грамматических категориях рода и одушевленности в современном русском языке, Вопроси языкознания, 4, 25-40.

Ивић 1960: Милка Ивић, Обележавање именичког рода у српскохрватском књижевном језику, Наш језик, X/7-10, 192-211.

Ивић 1966: Milka Ivić, Tipovi imeničkog roda u srpskohrvatskom književnom jeziku, Зборник за филологију и лингвистику, IX, 41-48.

Ивић 1967: Milka Ivić, O rodzaju i typach paradygmatycznych polskich rzeczowników, Studia z filologii polskiej i słowiańskiej, 6, 57-61.

Ивић 1968: Milka Ivić, Obeležavanje imeničkog roda u (standardnom) slovenačkom jeziku upoređeno s odgovarajućom srpskohrvatskom situacijom, Зборник Матице српске за филологију и лингвистику, XI, $49-55$.

Кликовац 2002: Душка Кликовац, Граматика српскога језика за основну школу, Београд: Српска школска књига.

Николић 2004: Мирослав Николић, Природни и граматички род именица, Наш језик, XXXIV/3-4, 181-194.

Пипер и др. 2005: Предраг Пипер, Ивана Антонић, Владислава Ружић, Срето Танасић, Људмила Поповић, Бранко Тошовић, Синтакса савременога српског језика. Проста реченииа, Београд: Институт за српски језик САНУ, Београдска књига; Нови Сад: Матица српска.

Симић 1996: Радоје Симић, Српска граматика за средње школе I, Београд: Актуел. 
Станојчић/Поповић 1997: Живојин Станојчић, Љубомир Поповић, Граматика српскога језика, Београд: Завод за уџбенике и наставна средства.

Стевановић 1937: Михаило Стевановић, Ког је рода именица 'наочари', Наш језик, V/7-8, 204-208.

Стевановић 1975: Михаило Стевановић, Савремени српскохрватски језик I, Београд: Научна књига.

Томић 2011: Дина Томић, О категорији рода код именица, Научни састанак слависта у Вукове дане, 40/3, 209-221.

\section{THE GENDER OF THE NOUNS IN SLAVIC LANGUAGES AS A SEMANTICAL, MORPHOLOGICAL AND SYNTACTICAL CATEGORY - ON THE EXAMPLE OF THE NOUN $N A O \check{C} A R I$}

\section{Summary}

The paper proposes a new methodology for defining the gender of the nouns in Slavic languages on the example of the noun naočari, which is considered an exception in Serbian grammar. For that purpose we reconstruct and define the morphological paradigm of the noun in question and we observe the distribution of the adjective forms with it inside the syntactic group. The method of the analysis is distributional - we focus on the formal rules of binding the noun forms with the adjective forms, while semantics plays a control role (the syntactic group is evaluated as correct or incorrect, with no further semantic analyzing). For the purpose we have developed a special diagnostic technique of distributional tables, which show the correct combinations of nouns and adjectives, as well as incorrect and syncretic ones. Based on the sum of the correct forms of adjectives, a distributional class of the noun is defined, which illustrates the rules of combining the forms of the noun naočari with appropriate gender forms of the adjectives. The results of the experiment show that in the grammatical analysis, apart from morphological and semantical gender, the syntactical (distributional) gender must be considered too. Another conclusion is that certain theoretical innovations need to be introduced in the current definitions of gender and agreement, thanks to the established fact that the syntactical (distributional) class of the noun does not have to be the same as its morphological (grammatical) or semantical (natural) gender, as proven in the experiment.

Keywords: syntax, morphology, agreement, grammatical category of gender, noun gender, extrarelational function, intrarelational function, grammatical distribution 